\title{
The impact of time on the heat resistance of self-compacting high- performance concrete incorporated with recycled martials
}

\author{
Mohammed Abed ${ }^{1} \cdot$ Rita Nemes ${ }^{1} \cdot$ Éva Lublóy $^{1}$ \\ Received: 16 November 2018/ Accepted: 15 April 2019/Published online: 26 April 2019 \\ (C) The Author(s) 2019
}

\begin{abstract}
The influence of time on the mechanical behavior of concrete after exposure to elevated temperatures has been studied. Twenty-one self-compacting high-performance concrete mixtures with different incorporation amounts of coarse recycled concrete aggregate (RCA) and three unprocessed waste powder materials have been tested at age of 270 days for residual compressive and flexural strength after exposure to fire. The results have been compared to the results for the same concrete, which have been studied at age of 90 days. A new parameter has been introduced for comparing the responses of concrete to elevated temperatures at different ages; this parameter was the "heat resistance" which expresses the total area under the curve of the relative residual strength (compressive or flexural) after exposing to six temperature degrees (20, $150,300,500,600$, and $800^{\circ} \mathrm{C}$ ). The results showed that the age of concrete has an influence on the response of concrete to elevated temperatures. The heat resistance of compressive strength enhanced with age but the concrete behaved with a tendency different to that at the age of 90 days. The heat resistance of flexural strength has not been affected or slightly decreased but not with more than $10 \%$ to that at the age of 90 days. The used waste powder materials were unprocessed waste fly ash, waste cellular concrete powder and waste perlite powder; they proved that using any of them up to $15 \%$ as a replacement for cement with $0 \%$ or $25 \%$ of RCA enhanced the concrete resistance for the fire with time. The main two reasons for changing of residual strength with the time were the changing of water content and the proceeding of hydration of the binder. In general, long ages testing properties of concrete simulate the real behavior of concrete structures accurately.
\end{abstract}

Keywords Fire $\cdot$ Concrete $\cdot$ Recycled martials $\cdot$ Supplemetary materials

\section{Introduction}

Fire is one of the major hazards to which concrete structures could be susceptible during their service life. Results of long-term testing of the mechanical properties of concrete at elevated temperatures could be closer to reality than those of short-term evaluation. This could be more

Éva Lublóy

lubloy.eva@epito.bme.hu

Mohammed Abed

abed.mohammed@epito.bme.hu

Rita Nemes

nemes.rita@epito.bme.hu

1 Department of Construction Materials and Technologies, Faculty of Civil Engineering, Budapest University of Technology and Economics, Budapest 1521, Hungary necessary during use of additives, many of which consume a long time to complete the hydration process. Technological advances introduced new kinds of concrete like self-compacting high-performance concrete (SCHPC) incorporated with coarse recycled concrete aggregates (RCA), where by utilizing the construction waste a sustainable value can be added in addition to the technical value. However, it was revealed that the behavior of the new kinds of concrete after exposure to elevated temperatures is very different compared with traditional concretes [1-3].

Self-compacting concrete (SCC) is that kind of concrete, which has a high filling ability to all sections of the forms without the need for a mechanical vibrator [4]. Recently its using has been widely grown in the construction industry and it is predicted to be in high demand in the near future [5]. A limited number of researchers have been studied the 
residual mechanical properties of SCC after exposure to elevated temperatures and concluded that SCC responses with more deterioration of residual mechanical properties and higher susceptibility to spalling especially at beyond $300{ }^{\circ} \mathrm{C}$ comparing with the normal vibrated concrete [3, 6-10].

SCHPC produced by using RCA is not discussed in details at the literature; however, it could be concluded that the behavior of recycled aggregate concrete (RAC) after exposure to elevated temperatures is that using RCA decreases the possibility of explosive spalling and increases the residual mechanical properties compared to the reference natural aggregate concretes [11-15]. This behavior is related to the strong interface between new and old adhered mortars and also the lower water-to-binder ( $w$ / b) ratio which contributes to increase the residual strength of RAC after exposing to elevated temperatures [16].

No available studies have discovered the long-term response to elevated temperatures, but the study of longterm residual strength at elevated temperatures could simulate reality more accurately than could investigations conducted only at short-term; moreover, there are no studies investigated the effects of the unprocessed waste powder materials on SCHPC incorporated with RCA subjected to elevated temperatures. The present study aims at studying the long-term residual strength for twenty-one SCHPC mixtures with different replacement amounts of coarse natural aggregate (NA) and cement by RCA and unprocessed waste powder materials, respectively. Then a comparison has been done between the results of this study, which was conducted at age of 270 days of concrete, with the results of the same concrete mixtures at age of 90 days.

\section{Experimental}

\section{Applied materials}

Portland cement (CEMI42.5N) and three different unprocessed waste powder materials have been used to conduct the present study. The waste powder materials that partially replaced the cement by mass were

1. Unprocessed waste fly ash (UWFA) collected from Visonta coal-fired thermal power station in Hungary and delivered to the laboratory without any processing,

2. Waste cellular concrete powder (WCCP) which is a waste material collected from a factory for cutting cellular concrete masonry in Hungary,

3. Waste perlite powder (WPP) which is amorphous volcanic silicate/alumina rock originating from raw perlite resulting from cutting the raw perlite rock; Hungary is considered one of the main countries for producing perlite [17]. WPP has been imported with two fractions of particles, WPP-c and WPP-s high and low specific surface area, which were used in the present study by $50 \%$ of each as WPP.

By chemical analytical methods, the oxidizing composition has been determined; although tested materials are unprocessed waste materials, they contain mostly amorphous materials, and the differences have been identified by X-ray diffraction. The X-ray diffraction profile is shown in Fig. 1, where the chemical and physical properties of the cement and the waste powder materials are shown in (Table 1) which were tested in accordance with the EN standards [18, 19]. In Fig. 1, the abbreviations are: A: Alite (C3S). B: Belite (C2S). C: Brownmillerite (C4AF). D: Gypsum (CSH2). E: Gypsum un-hydrated (CS). H: Hematite. K: Kaolinite. P: Plagioclase (Lattice). Q: Quartz. R: Phyllosilicates. S: Plagioclase (Anorthite). T: Tobermorite. Figure 2 shows the sieve curves for both cement and the waste powder materials. However, the crystalline phases could be identified as:

1. Cement (CEM I): $\mathrm{Ca}_{3} \mathrm{SiO}_{5}\left(\mathrm{C}_{3} \mathrm{~S}\right.$, alite, hatrurite) as main crystalline component; $\mathrm{Ca}_{2} \mathrm{SiO}_{4}\left(\mathrm{C}_{3} \mathrm{~S}\right.$, belite, larnite) presence cannot be excluded; $\mathrm{CaSO}_{4} \cdot 2 \mathrm{H}_{2} \mathrm{O}$ (CSH2, gypsum); $\mathrm{Ca}_{4} \mathrm{Al}_{2} \mathrm{Fe}_{2} \mathrm{O}_{10} \quad$ (C4AF, brownmillerite),

2. UWFA: alpha-SiO $\mathrm{S}_{2}(\mathrm{~S}, \mathrm{Alpha-quartz})$ as main crystalline component; $\mathrm{Fe}_{2} \mathrm{O}_{3}$ (F, hematite) also dominating crystalline component; $\mathrm{CaSO}_{4}$ (CS, anhydrite); plagioclase (feldspar, most probable heat-treated albite),

3. WPP: $\mathrm{SiO}_{2}(\mathrm{Ca}, \mathrm{Al}$ bearing cristobalite) as main crystalline component; plagioclase (feldspar, most probable anorthite); occurrence of various zeolitically hydrated minerals cannot be excluded,

4. WCCP: alpha-SiO $\mathrm{S}_{2}(\mathrm{~S}$, alpha-quartz) as the main crystalline component; $\mathrm{CaSO}_{4}$ (CS, anhydrite); hydrated mineral, called tobermorite $11 \mathrm{~A}$, seems to explain several diffraction peaks.

Natural aggregate and RCA have been used in the present study; the natural aggregate was quartz sand with a small fraction $(0 / 4 \mathrm{~mm})$ and NA with a coarse fraction (4/ $16 \mathrm{~mm}$ ). The RCA was just with a coarse fraction (4/ $16 \mathrm{~mm}$ ) produced by crushing and sieving of normal strength concrete cubes at the laboratory after testing. The densities for both NA and RCA are close; however, the Los Angeles wear and water absorption of RCA are relatively higher compared with NA, where there are $36.11 \%$ and $5.6 \%$ for RCA and $26.3 \%$ and $1.01 \%$ for NA. The particle size distributions for the three aggregate mixtures are shown in Fig. 3. The fractions of the aggregate were $45 \%$ for the small fraction and $55 \%$ for the coarse fraction; 
Fig. $1 \mathrm{X}$-ray diffraction profile for cement and the waste powder materials

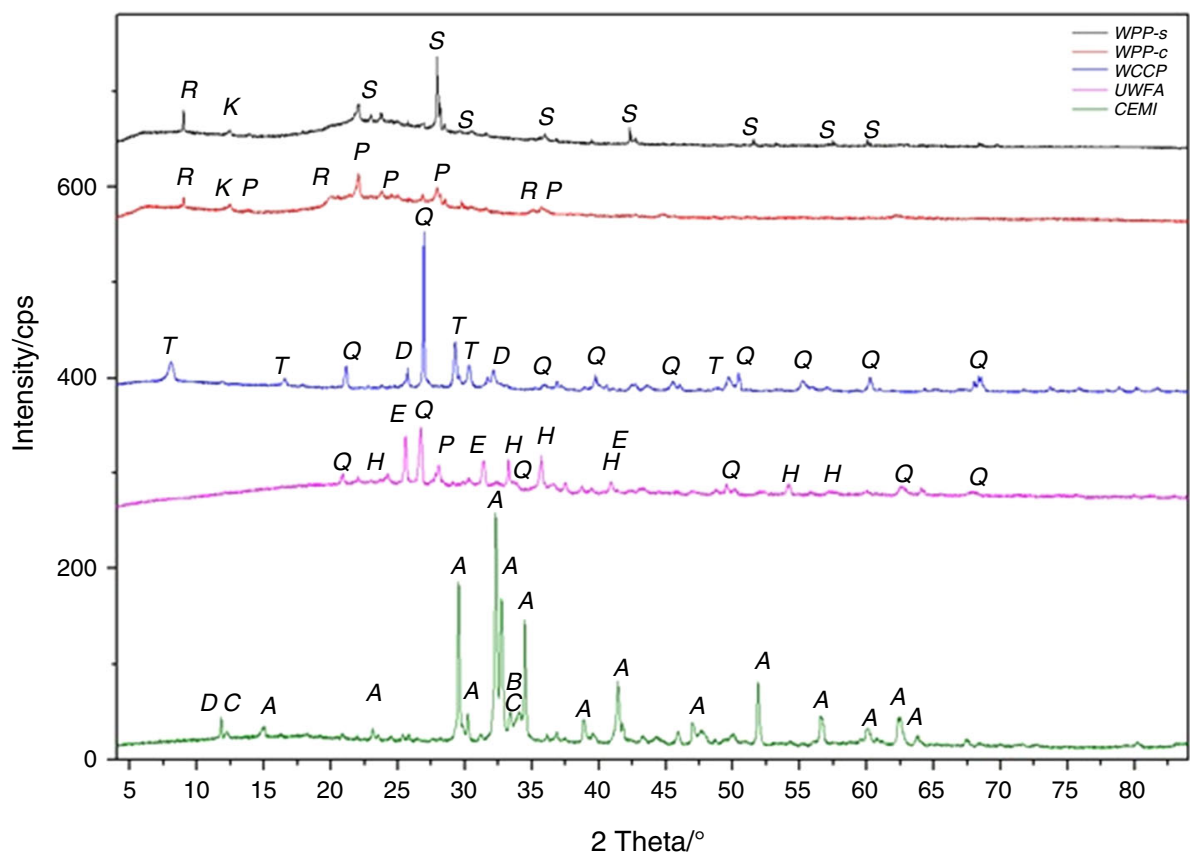

Table 1 Chemical compositions and physical properties of cement and waste powder materials

\begin{tabular}{|c|c|c|c|c|c|}
\hline Measured property & CEM I & UWFA & WPP-c & WPP-s & WCCP \\
\hline Density/g cm ${ }^{-3}$ & 3.02 & 2.15 & 2.33 & 2.33 & 1.96 \\
\hline Specific surface area $/ \mathrm{cm}^{+2} \mathrm{~g}^{-1}$ & 3326 & 4323 & 843.3 & 4159 & 2513 \\
\hline Loss on ignition & 3.0 & 1.95 & 2.8 & 1.21 & 9.25 \\
\hline $\mathrm{SiO}_{2}$ & 19.33 & 43.02 & 73.8 & 73.2 & 54.28 \\
\hline $\mathrm{CaO}$ & 63.43 & 15.07 & 1.7 & 1.06 & 22.81 \\
\hline $\mathrm{MgO}$ & 1.45 & 3.14 & 0.11 & 0.2 & 1.15 \\
\hline $\mathrm{Fe}_{2} \mathrm{O}_{3}$ & 3.42 & 14.17 & 2.57 & 2.6 & 2.16 \\
\hline $\mathrm{Al}_{2} \mathrm{O}_{3}$ & 4.67 & 15.6 & 13.8 & 16.6 & 5.09 \\
\hline $\mathrm{SO}_{3}$ & 2.6 & 3.56 & - & - & 4.90 \\
\hline Chloride content & 0.04 & 0.02 & - & - & 0.02 \\
\hline Free $\mathrm{CaO}$ & 0.71 & 0.37 & - & - & - \\
\hline $\mathrm{K}_{2} \mathrm{O}$ & - & - & 4.01 & 3.5 & - \\
\hline $\mathrm{Na}_{2} \mathrm{O}$ & - & - & 2.66 & 1.5 & - \\
\hline $\mathrm{TiO}_{2}$ & - & - & 0.083 & 0.09 & - \\
\hline Insoluble part in dilute hydrochloric acid and sodium carbonate & 0.26 & 49.72 & 92.07 & 86.19 & 33.02 \\
\hline
\end{tabular}

however, the NA substitution ratios by RCA were $0 \%$, $25 \%$, and $50 \%$ by mass; meanwhile, aggregate blends curves lie in the grading curve of EN standard [20].

\section{Concrete mixtures}

Twenty-one concrete mixtures have been produced through three series, and the main difference between the three series was the substitution ratios of NA by RCA; however, for each series seven mixtures have been produced with
$(0 \%, 15 \%$, and $30 \%)$ replacement of cement by each UWFA, WCCP, and WPP.

Table 2 shows the produced mixtures for the present study, w/b ratio and binder amount were constant through the present study, and they were 0.35 and $500 \mathrm{~kg} \mathrm{~m}^{-3}$, respectively, the water absorption of RCA has been compensated by adding extra water during mixing. Due to the low w/b ratio, a considerable amount of superplasticizer has been used to achieve the fresh properties of SCC, the superplasticizer was Sika ViscoCrete-5 Neu which is a 
Fig. 2 Grading curves of cement and waste powder materials

Fig. 3 Grading curves of different types of aggregates
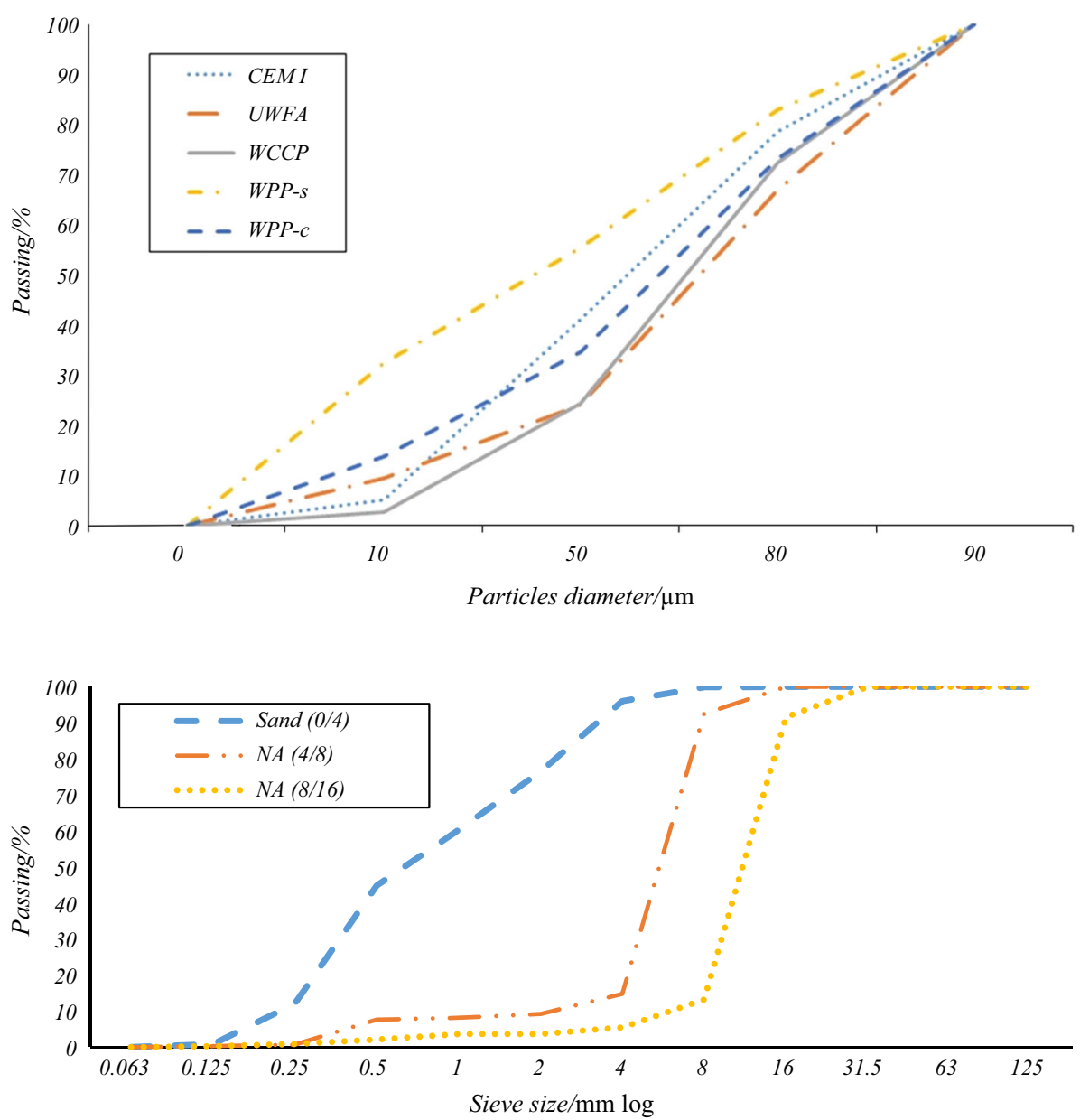

Table 2 Series mixtures matrix

\begin{tabular}{|c|c|c|c|c|}
\hline Series \# & $\begin{array}{l}\text { Replacement of } \\
\text { cement }\end{array}$ & $\begin{array}{l}0 \% \text { RCA replacement of coarse } \\
\text { aggregate }\end{array}$ & $\begin{array}{l}25 \% \text { RCA replacement of coarse } \\
\text { aggregate }\end{array}$ & $\begin{array}{l}50 \% \text { RCA replacement of coarse } \\
\text { aggregate }\end{array}$ \\
\hline Series I & $0 \%$ & RA0 & RA25 & RA50 \\
\hline Series II & $15 \%$ UWFA & F15RA0 & F15RA25 & F15RA50 \\
\hline $\begin{array}{l}\text { Series } \\
\text { III }\end{array}$ & $30 \%$ UWFA & F30RA0 & F30RA25 & F30RA50 \\
\hline $\begin{array}{l}\text { Series } \\
\text { IV }\end{array}$ & $15 \%$ WCCP & C15RA0 & C15RA25 & C15RA50 \\
\hline $\begin{array}{l}\text { Series } \\
\text { V }\end{array}$ & $30 \%$ WCCP & C30RA0 & C30RA25 & C30RA50 \\
\hline $\begin{array}{l}\text { Series } \\
\text { VI }\end{array}$ & $15 \%$ WPP & P15RA0 & P15RA25 & P15RA50 \\
\hline $\begin{array}{l}\text { Series } \\
\text { VII }\end{array}$ & $30 \% \mathrm{WPP}$ & P30RA0 & P30RA25 & P30RA50 \\
\hline
\end{tabular}

modified polycarboxylates aqueous solution, and the mixing proportions for all mixtures are shown in Table 3.

\section{Testing and heating procedure}

The testing and heating procedure has been conducted as the following: 
Table 3 Concrete mixing proportioning

\begin{tabular}{|c|c|c|c|c|c|c|c|}
\hline \multirow[t]{3}{*}{ Name of mixture } & \multicolumn{7}{|c|}{ Proportions in $/ \mathrm{kg} \mathrm{m}^{-3}$} \\
\hline & \multirow{2}{*}{$\begin{array}{l}\text { CEM I } \\
42.5 \mathrm{~N}\end{array}$} & \multirow[t]{2}{*}{ Waste powder material } & \multirow{2}{*}{$\begin{array}{l}\text { Fine aggregate } \\
\text { N. Sand } \\
0 / 4\end{array}$} & \multicolumn{2}{|c|}{ Coarse aggregate } & \multirow[t]{2}{*}{ Superplasticizer } & \multirow[t]{2}{*}{ Water } \\
\hline & & & & $\begin{array}{l}\text { NA } \\
4 / 16\end{array}$ & RCA & & \\
\hline \multicolumn{8}{|l|}{ Series I } \\
\hline RA0 & 500 & 0 & 783 & 939 & 0 & 1.5 & 175 \\
\hline RA25 & 500 & 0 & 783 & 704 & 230 & 1.5 & 175 \\
\hline RA50 & 500 & 0 & 783 & 470 & 460 & 1.5 & 175 \\
\hline \multicolumn{8}{|l|}{ Series II } \\
\hline F15RA0 & 425 & 75 & 767 & 920 & 0 & 2 & 175 \\
\hline F15RA25 & 425 & 75 & 767 & 690 & 226 & 2 & 175 \\
\hline F15RA50 & 425 & 75 & 767 & 460 & 251 & 2 & 175 \\
\hline \multicolumn{8}{|l|}{ Series III } \\
\hline F30RA0 & 350 & 150 & 751 & 901 & 0 & 3 & 175 \\
\hline F30RA25 & 350 & 150 & 751 & 475 & 221 & 3 & 175 \\
\hline F30RA50 & 350 & 150 & 751 & 451 & 442 & 3 & 175 \\
\hline \multicolumn{8}{|l|}{ Series IV } \\
\hline C15RA0 & 425 & 75 & 766 & 919 & 0 & 1.7 & 175 \\
\hline C15RA25 & 425 & 75 & 766 & 690 & 225 & 1.7 & 175 \\
\hline C15RA50 & 425 & 75 & 766 & 459 & 451 & 1.7 & 175 \\
\hline \multicolumn{8}{|l|}{ Series V } \\
\hline C30RA0 & 350 & 150 & 750 & 899 & 0 & 3.25 & 175 \\
\hline C30RA25 & 350 & 150 & 750 & 674 & 220 & 3.25 & 175 \\
\hline C30RA50 & 350 & 150 & 750 & 451 & 442 & 3.25 & 175 \\
\hline \multicolumn{8}{|l|}{ Series VI } \\
\hline P15RA0 & 425 & 75 & 774 & 928 & 0 & 3 & 175 \\
\hline P15RA25 & 425 & 75 & 774 & 697 & 228 & 3 & 175 \\
\hline P15RA50 & 425 & 75 & 774 & 464 & 455 & 3 & 175 \\
\hline \multicolumn{8}{|l|}{ Series VII } \\
\hline P30RA0 & 350 & 150 & 766 & 918 & 0 & 3.75 & 175 \\
\hline P30RA25 & 350 & 150 & 766 & 688 & 225 & 3.75 & 175 \\
\hline P30RA50 & 350 & 150 & 766 & 459 & 450 & 3.75 & 175 \\
\hline
\end{tabular}

Table 4 The number and shape of the test specimens

\begin{tabular}{|c|c|c|c|c|c|c|}
\hline Test & Specimen & $\begin{array}{l}\# \text { of } \\
\text { specimens }\end{array}$ & $\begin{array}{l}\text { \# of maximum } \\
\text { temperatures }\end{array}$ & $\begin{array}{l}\# \text { of testing } \\
\text { ages }\end{array}$ & $\begin{array}{l}\# \text { of } \\
\text { mixtures }\end{array}$ & $\begin{array}{l}\text { Total number of } \\
\text { specimens }\end{array}$ \\
\hline $\begin{array}{l}\text { Compressive } \\
\text { strength }\end{array}$ & $\begin{array}{l}\text { Cube } \\
(150 \times 150 \times 150 / \\
\mathrm{mm})\end{array}$ & 3 & 6 & 2 & 21 & 756 \\
\hline Flexural strength & $\begin{array}{l}\text { Prism }(70 \times 70 \times 250 / \\
\mathrm{mm})\end{array}$ & 3 & 6 & 2 & 21 & 756 \\
\hline Total & & & & & \multicolumn{2}{|c|}{1512 specimens } \\
\hline
\end{tabular}

1. Casting the specimens with the standard molds for testing the compressive and flexural strengths, the number of specimens through the present study is shown in Table 4, 
2. After $24 \pm 2 \mathrm{~h}$ of casting, the specimens have been demolded and emerged in water,

3. After 7 days for water curing, the specimens have been got out from the water and stored in lab conditions at $20 \pm 2{ }^{\circ} \mathrm{C}$ and $35 \%$ relative humidity until the day of tests,

4. At age of $90 \pm 5$ days ( 3 months), the testing program has been conducted, and at age of $270 \pm 5$ days (9 months) the testing program has been repeated,

5. The heating system has been applied for each specimen by heating up the specimens up to the maximum temperature for two hours, and the maximum temperatures were: $20,150,300,500,600$ and $800{ }^{\circ} \mathrm{C}$,

6. Then, the specimens have been left in the laboratory condition for the purpose of cooling them down.

The temperature range from 20 to $800{ }^{\circ} \mathrm{C}$ is the same of the temperature range, which could occur for $1 \mathrm{~h}$ in a real fire situation [21]. The heating curve was similar to the standard fire ISO 834 curve for buildings up to $800{ }^{\circ} \mathrm{C}$, where the standard fire ISO 834 curve is shown in Fig. 4.

\section{Results}

The residual mechanical properties (compressive strength and flexural strength) after temperature elevation are presented in this section. The residual mechanical properties after temperature elevation were tested at two ages, namely 90 and 270 days, the first of which is recommended by RELIM and the second of which was proposed in the current work in an attempt to reflect the behavior of real structures at elevated temperatures. Relative residual strength, as a function of temperature, is presented in this section; it was calculated by division of the residual strength after each single temperature degree by the strength of the same mixture at the ambient temperature. The relative residual strength was calculated separately for compressive and flexural strengths, i.e., relative residual

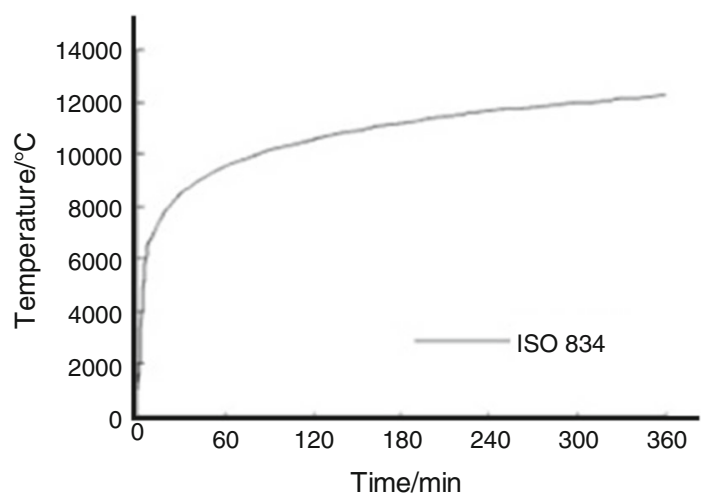

Fig. 4 ISO-834 fire curve compressive strength and relative residual flexural strength. Given the large numbers of the curves and the complexity of comparing the results on days 90 and 270, the effect of temperature elevation with the different ages of the concrete was determined through calculation of the total area under the curve of the relative residual strength $\left(20-800{ }^{\circ} \mathrm{C}\right)$. This area was then expressed by a new parameter called heat resistance, which was calculated separately for the compressive and flexural strengths, i.e., heat resistance of compressive strength and heat resistance of flexural strength.

\section{Results at laboratory temperature}

The consistency of the fresh concrete mixtures has been tested by slump flow (slump diameter in $\mathrm{cm}$ ) and V-Funnel (flow time in s) to verify the achievement of SCC properties. All mixtures have satisfied the European guideline for SCC [22]. The hardened mechanical properties have been tested as well at ambient temperature at 90 and 270 days, where the rate of gain of strength in RAC was higher after 1 month as compared to that of NA concrete [23-25]. Figure 5 shows the compressive and flexural strength results after 3 months for all the twenty-one mixtures; by increasing the RCA dosage up to $50 \%$, the compressive and flexural strength increase and this behavior could be related to many reasons as concluded in the literature:

1. The adhered mortar on RCA could contain un-hydrated cement, which contributes to strength gains by age [26],

2. The increased roughness, porosity and specific surface of the RCA contribute to enhancing interconnection between the RCA and the new mortar than for the NA concrete and enables a better mechanical bonding between the cement matrix and the RCA [27-29],

3. The good control of RCA grading as well as the high grade of the concrete $[30,31]$.

However, using up to $15 \%$ replacement of cement by unprocessed waste powder materials does not change the mechanical properties significantly of RAC or even enhance them like in case of using WPP, where they contribute to improving the interfacial transition zone (ITZ).

\section{Results after elevated temperatures}

\section{Impact of RCA and/or waste powder materials replacement (compressive strength)}

Figure 6 shows the development of relative residual compressive strength as a function of temperature and age of 
Fig. 5 Compressive and flexural strength at laboratory temperature $\left(20 /{ }^{\circ} \mathrm{C}\right)$ at 90 and 270 days

Fig. 6 Relative residual compressive strength as a function of temperature of SCHPC incorporated with RCA
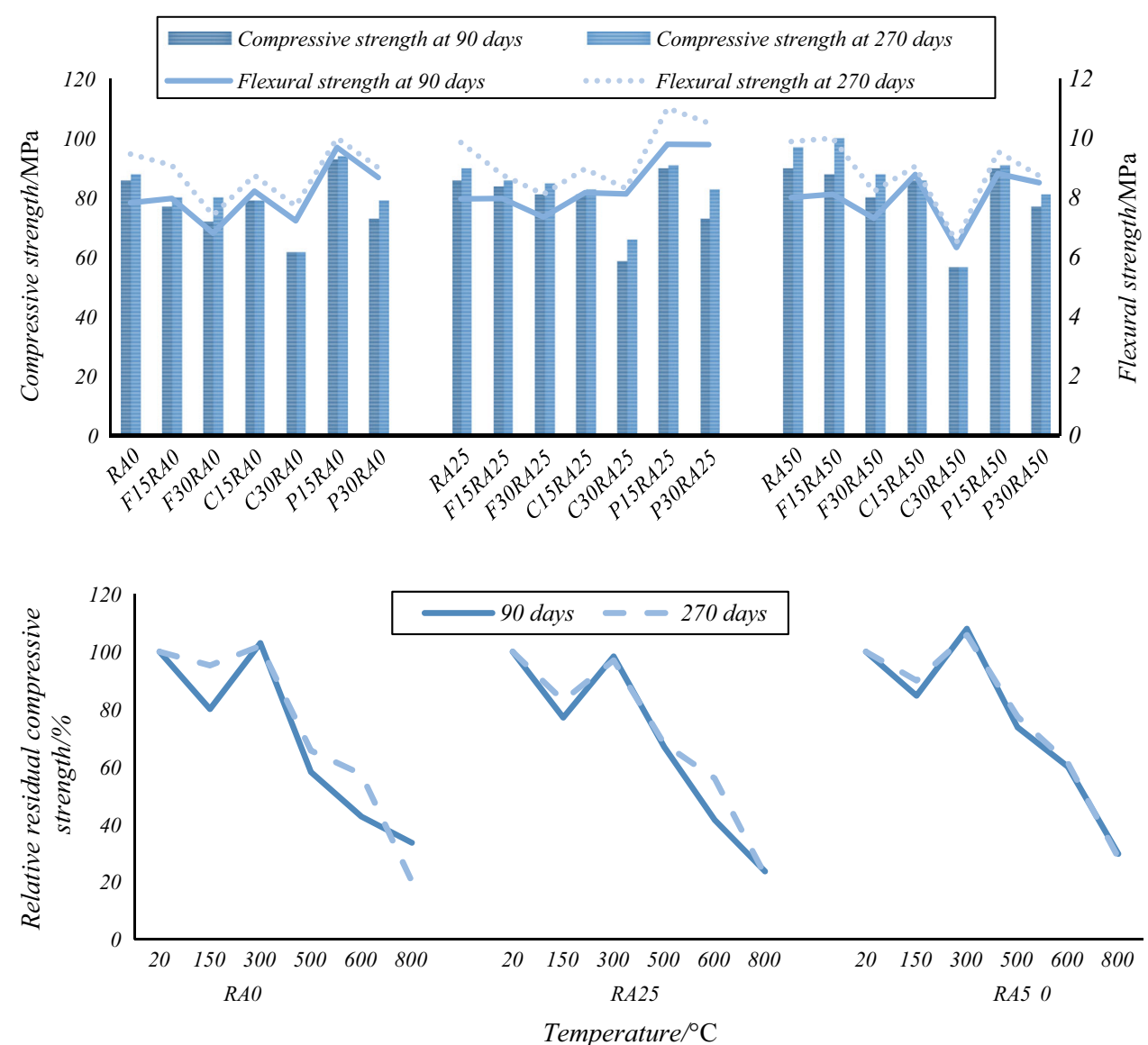

concrete; three replacement percentages of NA by RCA are depicted (RA0, RA25 and RA50). According to Fig. 6, a drop in residual compressive strength at $150{ }^{\circ} \mathrm{C}$ remained visible on day 270 but was less than the drop in value on day 90. The decrease in moisture content and hydration of the concrete with age could explain this phenomenon. However, in the case of using RCA, SCHPC could save its moisture for a prolonged time and behaved with a simple tendency during the 90-day test. On day 270, neither NA nor RCA exhibited spalling.
Figure 7 shows the development of relative residual compressive strength as a function of temperature and age of concrete with waste powder materials replacement for the three optimal SCHPCs. Adoption of $15 \%$ of any of the used waste powder materials with $25 \%$ RCA could enhance the resistance of SCHPC against high temperatures and make its positive effect more significant on day 270 . UWFA did not remarkably affect the fire resistance at the age of 270 days compared with the age of 90 days, when it behaved similarly as did the cement binder in the RA25
Fig. 7 Relative residual compressive strength as a function of temperature of SCHPC incorporated with RCA and waste powder materials (the optimal mixtures)

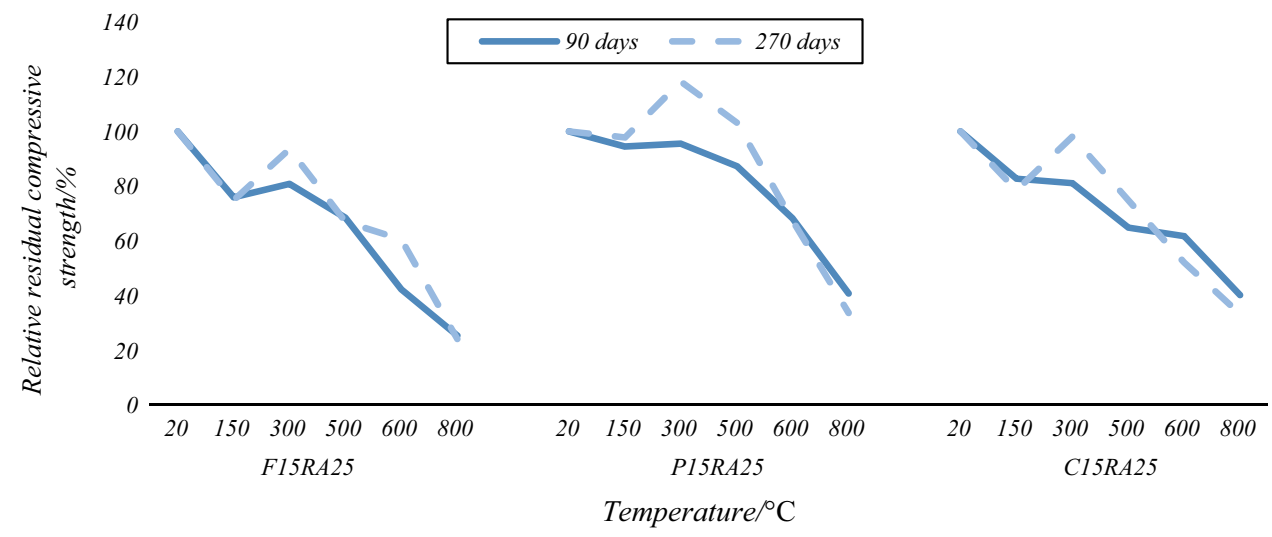


mixture. The UWFA composition was close to the cement composition, but it enhanced the residual compressive strength after considerable temperature elevation due to the excessive hydration of UWFA with age.

WPP had the best influence on resisting high temperatures on day 90 or 270 compared with UWFA and WCCP. Furthermore, WPP enhanced the residual compressive strength of SCHPC up to $600{ }^{\circ} \mathrm{C}$. This condition could be related to its composition, which featured a small amount of $\mathrm{CaO}$ and contained other minerals, such as $\mathrm{TiO}_{2}$ and $\mathrm{Na}_{2} \mathrm{O}$, which enhanced the fire resistance at high temperatures.

Lublóy et al. [32] concluded that the low $\mathrm{CaO} / \mathrm{SiO}_{2}$ ratio of the binder means higher relative residual compressive strength concrete after the thermal load of $800{ }^{\circ} \mathrm{C}$, and the ratios of the three main oxides $\left(\mathrm{SiO}_{2}, \mathrm{CaO}, \mathrm{Al}_{2} \mathrm{O}_{3}\right)$ of the three waste powder materials are shown in Fig. 8, which shows that $\mathrm{CaO}$ in the three waste powder material is relatively low, but in case of WPP it is very low compared to the amount of $\mathrm{SiO}_{2}$. With age, the water content decreased, thereby enhancing fire resistance at $300{ }^{\circ} \mathrm{C}$. WCCP did not show a noticeable positive effect on day 90 , but its

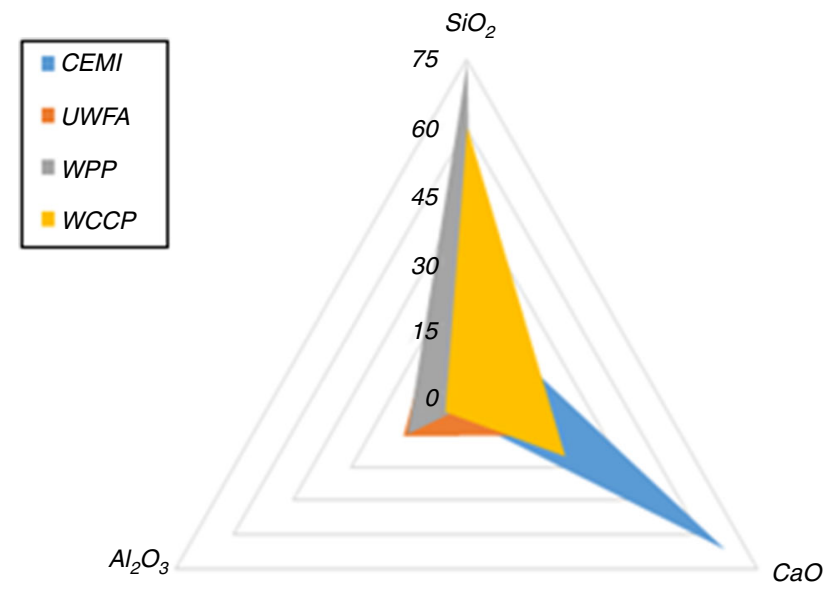

Fig. 8 Ratios of the three main oxides in cement compositions behavior improved on day 270 due to its hydration with age. In general, use of any of the waste powder materials by up to $15 \%$ is good from the perspective of environmental sustainability in addition to their capability to enhance fire resistance.

Figure 9 shows that the heat resistance of compressive strength of all the concrete mixtures generally improved with age, and this outcome was due to the increase in strength and reduction in water content with age. The decrease in the moisture content of concrete with age causes a change in the tendencies of residual compressive strength at elevated temperatures. Using $15 \%$ cement replacement by any of the waste powder materials is preferable with up to $25 \%$ RCA. The increase in heat resistance of compressive strength with age did not exceed $7 \%$ Meanwhile, the decrease in did not exceed $1.5 \%$ and was thus negligible. Therefore, using $30 \%$ cement replacement by any of the waste powder materials is not preferable; an excessive dosage of waste powder materials with RCA could be ineffective in resisting elevated temperatures over long terms, especially with the expansion behavior of adhered mortar on RCA and the completely different appearance of the new mortar.

\section{Impact of RCA and/or waste powder materials replacement (flexural strength)}

Figure 10 shows the development of relative residual flexural strength as a function of temperature and age of concrete; three replacement percentages of NA by RCA are presented (RA0, RA25 and RA50). As shown in Fig. 10, the flexural strength behavior of SCHPC after temperature elevation decreased with age, but it behaved in the same tendency at 90 days. Meanwhile, the water content in the ITZs played an important role in enhancing the flexural strength. The values of residual flexural strength generally decreased slightly or were not affected by the progression of concrete age; any such decrease was only small and therefore negligible.
Fig. 9 Heat resistance of compressive strength at 90 and 270 days $\left[20-800 /{ }^{\circ} \mathrm{C}\right]$

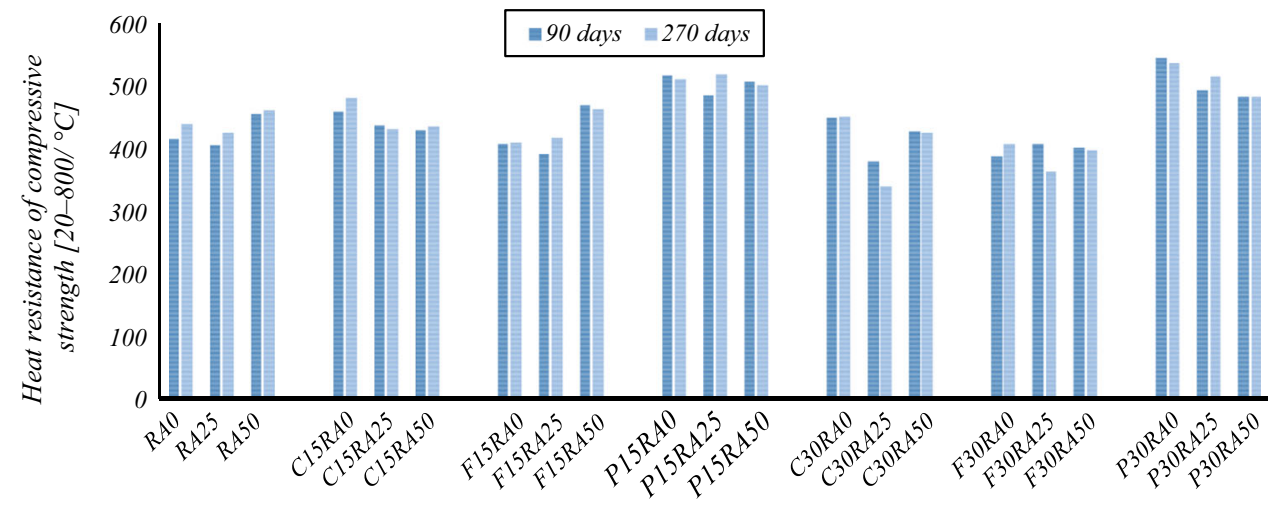


Fig. 10 Relative residual flexural strength as a function of temperature of SCHPC incorporated with RCA
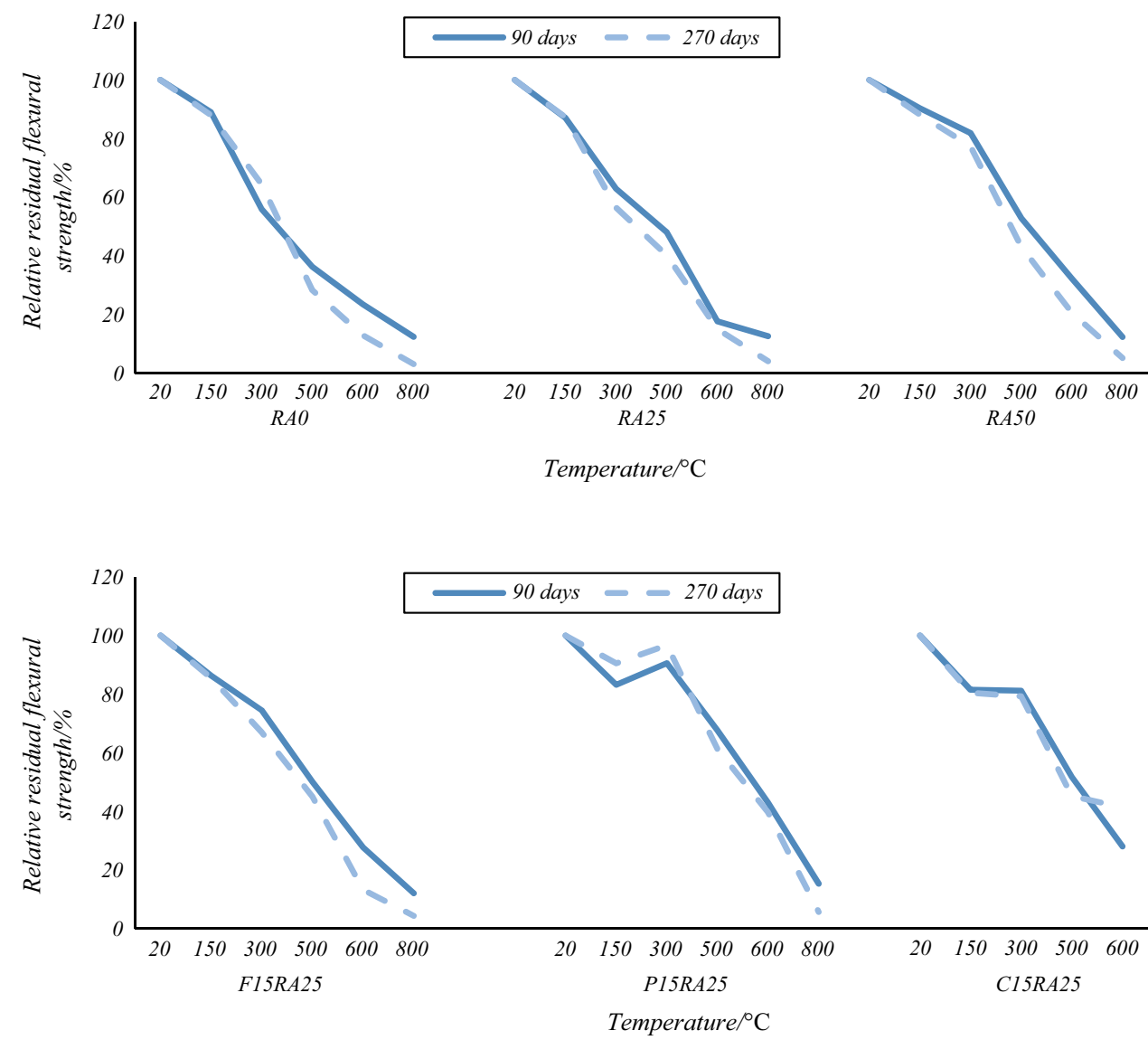

Fig. 11 Relative residual flexural strength as a function of temperature of SCHPC incorporated with RCA and waste powder materials (the optimal mixtures)

Fig. 12 Heat resistance of flexural strength at 90 and 270 days $\left[20-800 /{ }^{\circ} \mathrm{C}\right]$

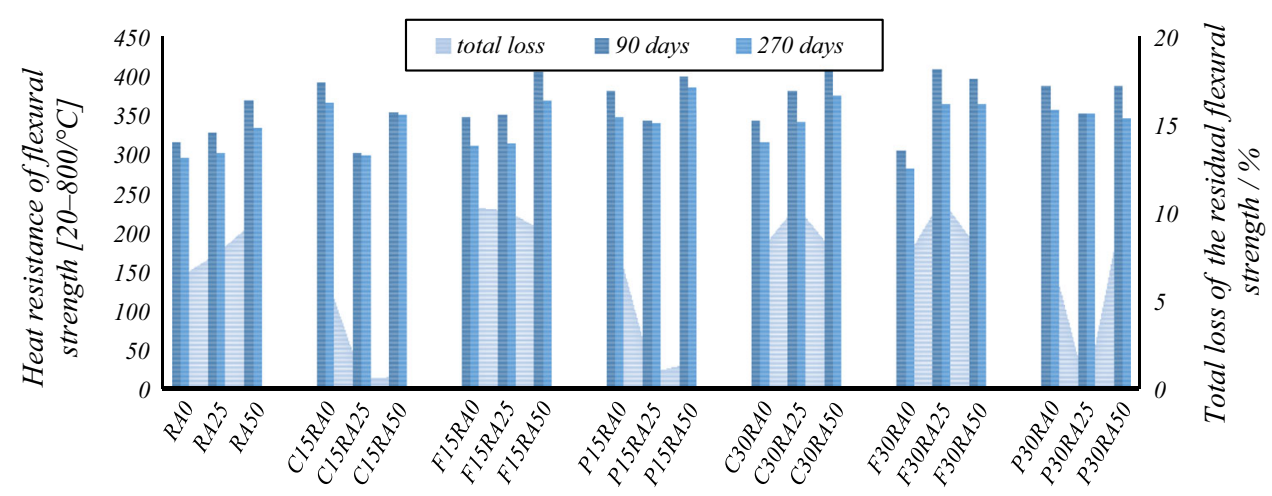

The optimal mixtures with any of the three waste powder materials with RCA are shown in Fig. 11, where the optimal replacement of cement by any waste powder material was up to $15 \%$. However, at the age of 270 days, the concrete behaved with a tendency similar to that at the age of 90 days, when the decrease in water content at the ITZs caused a small reduction in fire resistance.

Age negatively affected the heat resistance of flexural strength, which decreased by $10 \%$ at most at the age of 270 days, compared with 90 days' heat resistance. Figure 12 shows the heat resistance of concrete on days 90 and
270 and depicts the total loss of heat resistance by the hatched area. As illustrated in Fig. 12, the loss of flexural strength heat resistance increased with the amount of RCA replacement. However, with use of WPP, the loss of heat resistance could be neglected, especially in case of RAC, due to its small fraction particles' enhancement of the ITZs.

In case of non-use of any waste powder materials or with use of UWFA, the tendency of the residual flexural strength after fire did not change significantly. At 270 days, the residual flexural strength decreased significantly at 
$800{ }^{\circ} \mathrm{C}$; they were between 3 and $6 \%$ of the flexural strength at ambient temperature in all cases. However, the maximum decrease heat resistance of flexural strength for all mixtures did not exceed $10 \%$.

\section{Conclusions}

The main objective of the present study is to investigate the effect of age and elevated temperatures on the residual both compressive and flexural strengths of concrete produced by incorporating recycled concrete aggregate (RCA) and unprocessed waste powder materials. The effect of waste powder materials in case of elevated temperatures is not covered in the literature likewise the self-compacting highperformance concrete. The present study was experimentally examined at age of 270 days of the specimens regarding the following parameters: (a) The amount of RCA replacement $(0,25$ and 50\%). (b) The type of waste powder materials (unprocessed waste fly ash (UWFA), waste cellular concrete powder (WCCP), waste perlite powder (WPP)). (c) The amount of waste powder materials replacement $(0,15$ and $30 \%)$. (d) The maximal temperature $\left(20,150,300,500,600\right.$, and $\left.800^{\circ} \mathrm{C}\right)$. (e) The age of specimens (90 days and 270 days). However, the following conclusions could be drown:

\section{Compressive strength}

1. A drop in residual compressive strength at $150{ }^{\circ} \mathrm{C}$ remained visible on day 270 but was less than the drop in value on day 90 . The decrease in moisture content and hydration of the concrete with age could explain this phenomenon. However, in the case of using RCA, SCHPC could save its moisture for a prolonged time and behaved with a simple tendency during the 90-day test.

2. The heat resistance of compressive strength in SCHPC generally improved with age, and this outcome was due to the increase in strength and reduction in water content with age.

3. Replacing of cement up to $15 \%$ by any of the proposed waste powder materials is preferable, but replacing of cement up to $30 \%$ is not preferable, where replacing WPP up to $15 \%$ enhances the fire resistance significantly.

4. For all concrete types, no spalling was exhibited on day 270 test, regardless if the used coarse aggregate was NA or RCA.

\section{Flexural strength}

1. The values of residual flexural strength decrease slightly with time, and this decrease is only small and therefore negligible. However, the residual flexural strength at 270 days test behaves in the same tendency of 90-day test,

2. The loss of heat resistance of flexural strength increased by increasing the amount of RCA; however, using WPP or WCCP up to $15 \%$ decreases the loss of heat resistance of flexural strength compared to UWFA,

3. At 270 day, the residual flexural strength decreased significantly at $800{ }^{\circ} \mathrm{C}$, which was in all cases between 3 and $6 \%$ of the flexural strength at ambient temperature.

Acknowledgements Open access funding provided by Budapest University of Technology and Economics (BME). Authors are grateful to the Hungarian Scientific Research Fund (OTKA) for the financial support of the OTKA K 109233 research project, and support of Grant BME FIKP-VÍZ by EMMI is kindly acknowledged. The authors also acknowledge the support by the János Bolyai Research Scholarship of the Hungarian Academy of Sciences and ÚNKP-18-4 Scholarship.

Open Access This article is distributed under the terms of the Creative Commons Attribution 4.0 International License (http://creative commons.org/licenses/by/4.0/), which permits unrestricted use, distribution, and reproduction in any medium, provided you give appropriate credit to the original author(s) and the source, provide a link to the Creative Commons license, and indicate if changes were made.

\section{References}

1. Anderberg Y. Spalling phenomena of HPC and OC. In: Proceedings of international workshop on fire performance of highstrength concrete; 1997. p. 69-73.

2. Phan LT. High-strength concrete at high temperature: an overview. In: Proceedings of utilization of high strength/high performance concrete, 6th international symposium; 2002. vol. 1, p. 501-18.

3. Bakhtiyari S, et al. Self-compacting concrete containing different powders at elevated temperatures-mechanical properties and changes in the phase composition of the paste. Thermochim Acta. 2011;514(1):74-81.

4. Domone PL. Self-compacting concrete: an analysis of 11 years of case studies. Cem Concr Compos. 2006;28(2):197-208.

5. Domone PL. A review of the hardened mechanical properties of self-compacting concrete. Cem Concr Compos. 2007;29(1):1-12.

6. Pineaud A, Pimienta P, Rémond S, Carré H. Mechanical properties of high performance self-compacting concretes at room and high temperature. Constr Build Mater. 2016;112:747-55.

7. Persson B. Fire resistance of self-compacting concrete, SCC. Mater Struct/Mater Constr. 2004;37(273):575-84.

8. Reinhardt HW, Stegmaier M. Self-consolidating concrete in fire. ACI Mater J. 2006;103(2):130-5. 
9. Hanaa F, Noumowe A, Sébastien R. Self-consolidating concrete subjected to high temperature: mechanical and physicochemical properties. Cem Concr Res. 2009;39(12):1230-8.

10. Pathak N, Siddique R. Properties of self-compacting-concrete containing fly ash subjected to elevated temperatures. Constr Build Mater. 2012;30:274-80.

11. Cree D, Green M, Noumowé A. Residual strength of concrete containing recycled materials after exposure to fire: a review. Constr Build Mater. 2013;45:208-23.

12. Sarhat SR, Sherwood EG. Residual mechanical response of recycled aggregate concrete after exposure to elevated temperatures. J Mater Civ Eng. 2013;25(11):1721-30.

13. Vieira JPB, Correia JR, de Brito J. Post-fire residual mechanical properties of concrete made with recycled concrete coarse aggregates. Cem Concr Res. 2011;41(5):533-41.

14. Laneyrie $C$, et al. Influence of recycled coarse aggregates on normal and high performance concrete subjected to elevated temperatures. Constr Build Mater. 2016;111:368-78.

15. Zega CJ, Di Maio AA. Recycled concrete exposed to high temperatures. Mag Concr Res. 2006;58(10):675-82.

16. Xiao J, Zhang C. Fire damage and residual strengths of recycled aggregate concrete. Key Eng Mater. 2007;348:937-40.

17. Rashad AM. A synopsis about perlite as building material-a best practice guide for civil engineer. Constr Build Mater. 2016;121:338-53.

18. MSZ EN 196-2 Cement testing methods. Part 2: Chemical analysis of cement. Budapest: Magyar Szabványügyi Testület; 2013. (in Hungarian)

19. MSZ EN 525-12 Chemical analysis of cement. Part 12: Determination of free lime content. Budapest: Magyar Szabványügyi Testület; 2014. (in Hungarian)

20. BS EN 12620:2002+A1. Aggregates for concrete. London: British Standards Institution; 2008.

21. Hlavička ÉL-V. Bond after fire. Constr Build Mater. 2017;132:210-8.

22. EFNARC. Specifications and guidelines for self-compacting concrete, English ed. European federation for specialist construction chemicals and concrete systems;2005.
23. Rahal K. Mechanical properties of concrete with recycled coarse aggregate. Build Environ. 2007;42(1):407-15.

24. Etxeberria $M$, et al. Influence of amount of recycled coarse aggregates and production process on properties of recycled aggregate concrete. Cem Concr Res. 2007;37(5):735-42.

25. Kou SC, Poon CS. Mechanical properties of 5-year-old concrete prepared with recycled aggregates obtained from three different sources. Mag Concr Res. 2008;60(1):57-64.

26. Katz A. Properties of concrete made with recycled aggregate from partially hydrated old concrete. Cem Concr Res. 2003;33(5):703-11.

27. Poon CS, Shui ZH, Lam L. Effect of microstructure of ITZ on compressive strength of concrete prepared with recycled aggregates. Constr Build Mater. 2004;18(6):461-8.

28. Poon CS, et al. Influence of moisture states of natural and recycled aggregates on the slump and compressive strength of concrete. Cem Concr Res. 2004;34(1):31-6.

29. de Oliveira MB, Vazquez E. The influence of retained moisture in aggregates from recycling on the properties of new hardened concrete. Waste Manag. 1996;16(1):113-7.

30. Abd Elhakam A, Mohamed AE, Awad E. Influence of selfhealing, mixing method and adding silica fume on mechanical properties of recycled aggregates concrete. Constr Build Mater. 2012;35:421-7.

31. Kou S-C, Poon C-S. Effect of the quality of parent concrete on the properties of high performance recycled aggregate concrete. Constr Build Mater. 2015;77:501-8.

32. Lublóy É, Kopecskó K, Balázs G, Restas A, Szilágyi I. Improved fire resistance by using Portland-pozzolana or Portland-fly ash cements. J Therm Anal Calorim. 2017;1:12. https://doi.org/10. 1007/s10973-017-6245-0.

Publisher's Note Springer Nature remains neutral with regard to jurisdictional claims in published maps and institutional affiliations. 